(2) Open Access Full Text Article

COMMENTARY

\title{
Immunopharmacology of ulipristal as an emergency contraceptive
}

This article was published in the following Dove Press journal:

International Journal of Women's Health

23 November 2011

Number of times this article has been viewed

\author{
Ralph P Miech \\ Department of Molecular \\ Pharmacology, Physiology and \\ Biotechnology, Warren Alpert School \\ of Medicine, Brown University, \\ Providence, RI, USA
}

\begin{abstract}
A new progesterone antagonist, ulipristal has been made available as an emergency contraceptive. Ulipristal's major mechanism of action as an emergency contraceptive has been ascribed to its ability to delay ovulation beyond the life span of the sperm. This paper analyzes the potential action of ulipristal (1) when unprotected intercourse and administration of ulipristal occur outside the fertility window and (2) when unprotected intercourse and administration of ulipristal occur at or within 24 hours of ovulation. When unprotected intercourse and the use of a single low dose of ulipristal occur outside of the fertility window, ulipristal behaves like a placebo. When unprotected intercourse and the use of a single low dose of ulipristal occur within the fertility window but before ovulation, ulipristal behaves like an emergency contraceptive by delaying ovulation and thereby preventing fertilization. When unprotected intercourse and the administration of ulipristal occur at or within 24 hours of ovulation, then ulipristal has an abortifacient action. It is proposed that the abortifacient mechanism of a low dose of ulipristal taken after fertilization but before implantation is due to the ability of ulipristal to block the maternal innate immune system to become immunotolerant to the paternal allogenic embryo. Progesterone's critical immunotolerant actions involving early pregnancy factor, progesterone-induced blocking factor, and uterine natural killer cells are compromised by ulipristal.
\end{abstract}

Keywords: innate immune system, early pregnancy factor, progesterone-induced blocking factor, uterine natural killer cells, selective progesterone receptor modulator

\section{Introduction}

Ulipristal is a progesterone antagonist that is being used as an emergency contraceptive (EC) to delay ovulation beyond the life span of the sperm and thus prevent fertilization. This paper describes an additional hypothesis that suggests that ulipristal in certain circumstances blocks the immunotolerance effects of progesterone on the maternal innate immune system (mIIS), resulting in the immunorejection of an embryo attempting to implant.

\section{Progesterone in pregnancy}

Progesterone exerts its hormonal effects by binding to specific genomic and nongenomic receptors. ${ }^{1,2}$ Progesterone regulates the inflammatory processes in the human endometrium during both menstruation and implantation of the embryo. ${ }^{3,4}$ Inadequate progesterone synthesis results in spontaneous abortions. ${ }^{5}$ Progesterone has immunomodulating effects on dendritic cells from female mice that result in inhibition of pro-inflammatory cytokine secretion, downregulation of major histocompatibility
Correspondence: Ralph P Miech 50 Woodcrest Drive, Riverside, Providence, RI 02915, USA

Tel + | $40|433043|$

Fax + I 40I 8631595

Email ralph_miech@brown.edu 
Class II expression and decreased T-cell proliferation. ${ }^{6}$ These effects can be reversed by mifepristone, a progesterone antagonist. ${ }^{7}$ Induction of postimplantation pregnancy termination by the use of high dose mifepristone is related to placental effects of mifepristone rather than on unknown effects of mifepristone on the embryo, ie, preimplantation pregnancy termination. Low dose mifepristone has been shown not to affect ovulation but to alter the in vitro maturation of dendritic cells, which favors the immunorejection of an embryo attempting to implant. ${ }^{8}$

\section{Selective progesterone receptor modulators}

Selective progesterone receptor modulators (SPRMs) are progesterone receptor ligands that exert a multitude of unique in vivo effects that are tissue-selective. ${ }^{9-12}$ SPRMs function as either agonists, antagonists, or mixed agonist/antagonists, depending upon the progesterone sensitive tissue affected by the SPRM. ${ }^{13,14}$ Ulipristal, a chemical and pharmacological analog of mifepristone, is a SPRM that is marketed as a second generation EC under the trade name, ella ${ }^{\circledR}$ (Laboratoire HRA Pharma, Paris, France). ${ }^{15-20}$ The pharmacology, pharmacokinetics, efficacy, and safety of ulipristal as an EC have been recently reviewed. ${ }^{21}$ Classifying ulipristal as a contraceptive versus classifying ulipristal as a contragestive have been analyzed. ${ }^{22}$ "This report will use the classical definitions of both abortion and contraceptive. Abortion is defined as the loss of the embryo occurring either at the preimplantation stage or at the post-implantation stage and contraception is defined as the prevention of fertilization."

\section{ECs}

ECs are employed after a single episode of either unprotected intercourse or condom failure. Levonorgesterel, a firstgeneration EC, is effective as an EC if taken within 72 hours after intercourse and if taken in the follicular phase and prior to the rising levels of lutenizing hormone (LH). ${ }^{23,24}$ Mifepristone, but not levonorgestrel, inhibits human blastocyst attachment to an in vitro endometrial culture model. ${ }^{25}$ Ulipristal's effectiveness as an EC is extended up to 120 hours after intercourse in the follicular phase and is also effective as an EC if taken during rising $\mathrm{LH}$ levels prior to ovulation. ${ }^{26-29}$

The mechanisms of action of mifepristone and levonorgestrel when used for emergency contraception have been described. ${ }^{24}$ The mechanism of action of low dose of ulipristal (30 mg) as an EC has been attributed exclusively to the mechanism of delaying ovulation for several days until the deposited sperm are no longer capable of fertilizing the ovum. ${ }^{27,30,31}$
Because ulipristal has a long biological half-life of 32 hours, it is able to delay ovulation past the life span of sperm. ${ }^{21}$ To date, there have been no reports of any immunopharmacologic adverse reactions attributed to the delay of ovulation by ulipristal. Sperm are capable of fertilizing an ovum from a few minutes after intercourse up to 5 days (120 hours) later by those sperm that were stored in the cervical crypts. On the other hand, the ovum is only capable of being fertilized for 24 hours after ovulation. ${ }^{32,33}$ Ulipristal has a placebo effect when both unprotected intercourse and the administration of ulipristal occur more than 24 hours after ovulation. However, there is a unique circumstance and time period in which ulipristal would have a direct abortifacient effect rather than a contraceptive effect. When unprotected intercourse occurs within the fertility window (ie, less than 120 hours ( 5 days) before ovulation or not more than 24 hours after ovulation) and ulipristal is taken after fertilization, then ulipristal would have an abortifacient effect. An abortifacient effect of ulipristal can occur when ulipristal is taken post-fertilization but prior to implantation, when the progesterone levels are relatively low. The following analysis proposes that ulipristal unleashes an immunological attack on the implanting embryo.

\section{Multiple mechanisms of action of ulipristal}

Ulipristal binds to selective progesterone receptors in the uterus and corpus luteum, resulting in three abortifacient mechanisms: (1) failure of the decidua to develop and become receptive to implantation of the blastocyst, (2) failure of secretions of uterine glands in the decidua to maintain an implanted embryo, and (3) the return of spontaneous uterine contractions. ${ }^{34-36}$ There is potentially a fourth mechanism involving the immunological rejection of the blastocyst's trophoblast cells in a host-versus-graft rejection mechanism during the embryo's attempt to implant into the decidua. This fourth mechanism, proposed in this paper, involves the mIIS during the first 5-10 days after fertilization. ${ }^{37}$

\section{Immunosuppression of the innate immune system in pregnancy}

For a pregnancy to be successful, one of the many vital actions of progesterone is its ability to induce selective immune tolerance of the mIIS toward the paternal allogeneic embryo, beginning with fertilization and extending through implantation. ${ }^{38-44}$ During implantation, this induced tolerance of the mIIS is unique in that the mIIS is still able to provide a defense against the bacteria that invade the decidua. ${ }^{45,46}$ Since the protective zona pellucida and the surrounding 
granulosa cells are of maternal origin, the mIIS is not triggered by the foreign paternal antigens on the encapsulated embryo. Thus, from fertilization to the shedding of the zona pellucida, the developing embryo is shielded from initiating an immunological attack. ${ }^{47}$ Activation of the innate immune system would result in pregnancy loss. ${ }^{48}$ After shedding of the zona pellucida, implantation of the blastocyst can begin, and several factors are involved in the initiation of the selective immunotolerance of an implanting paternal semi-allogeneic graft. ${ }^{49-51}$ For example, human leukocyte antigen $G$ plays a key role in implantation by modulating cytokine secretion to control trophoblastic cell invasion and to maintain a local immunotolerance. ${ }^{52-58}$ The decidua secretes glycodelin, a protein with proposed immunomodulatory activity during nidation. ${ }^{59}$ To avoid rejection, the villous trophoblast population of cells that are exposed to maternal blood lacks both major histocompatibility complex class I and class II molecules. ${ }^{60}$ Immunnotolerance is further aided by progesterone's ability to stimulate both systemic and uterine regulatory $\mathrm{T}$ cells, $\left(\mathrm{CD} 4{ }^{+} \mathrm{CD} 25^{+}\right.$Treg cells $)$so that antiinflammatory $\mathrm{T}$ helper $(\mathrm{Th})-2$ cells predominate over the proinflammatory Th-1 cells. ${ }^{61-66} \mathrm{Th}-1$ cells produce inflammatory cytokines associated with spontaneous abortion, while Th- 2 cells secrete anti-inflammatory cytokines associated with immunotolerance. ${ }^{67}$

Early pregnancy factor (EPF), progesterone-induced blocking factor (PIBF), and phenotypically altered decidua natural killer cells (DANK) are intimately involved in allowing the mIIS to set up a selective tolerance of the implanting embryo. ${ }^{68}$ Since both mifepristone and ulipristal alter the natural functioning of progesterone receptors involved in EPF, PIBF, and DANK, progesterone is prevented from inducing the necessary selective tolerance state of the mIIS cells in the decidua, the uterine stoma, and the corpus luteum. This allows mIIS cells to reject the implanting or newly implanted embryo.

\section{EPF}

Within microseconds after fertilization, the ion channels in the zygote's cell membrane open resulting in a permanent negative charge that sweeps across the surface of the zygote's cell membrane preventing additional sperm from gaining access to the interior of the fertilized ovum. Then, within minutes after fertilization, the zygote secretes an enzyme that changes the zona pellucida from a sol to a gel, which forms an additional barrier that sperm are not able to penetrate and protects the embryo from both physical damage and cellular immunological attack as the embryo begins its 5-7 day journey through the fallopian tube into the interior of the uterus. Within hours after fertilization, the developing embryo begins secretion of ovum factor, which stimulates progesterone-primed maternal ovaries to secrete EPF. EPF has immunomodulatory properties, and it is an extra cellular form of protein chaperonin $10 .{ }^{69-71} \mathrm{EPF}$ is the first of three mechanisms that suppresses the mIIS to prevent immunological rejection of the embryonic trophoblast cells. The invading trophoblast cells of the blastocyst constitute a semi-allograft that would be rejected without the suppression of the mIIS by progesterone. Developing trophoblasts of the embryo take over from the ovaries and maintain the secretion of EPF. EPF binds to a specific lymphocyte population that releases soluble suppressor factors. ${ }^{39}$ Figure 1 depicts the proposed mechanism by which EPF suppresses the mIIS.

A variety of cellular and signaling mechanisms use nuclear factor (NF)- $\kappa \beta$ to generate pro-inflammatory cytokines, inflammatory mediators, and cytotoxic cells as agents to protect humans from infections, tumors, and carcinogens. ${ }^{72,73} \mathrm{NF}-\kappa \beta$ is a ubiquitous transcription factor. Since $\mathrm{NF}-\mathrm{KB}$ functions as the master switch in immune system's protective mechanisms, NF- $\kappa \beta$ may operate in the rejection of semi-allogenic cells. ${ }^{50,74,75}$ Thus EPF could achieve immunosupression of uterine immune cells by activating I- $\kappa \beta$, the naturally occurring inhibitor of NF- $\kappa \beta .^{76}$

\section{PIBF}

In pregnant mice, due to endocrine stimulation by progesterone, spleenic lymphocytes synthesize and secrete

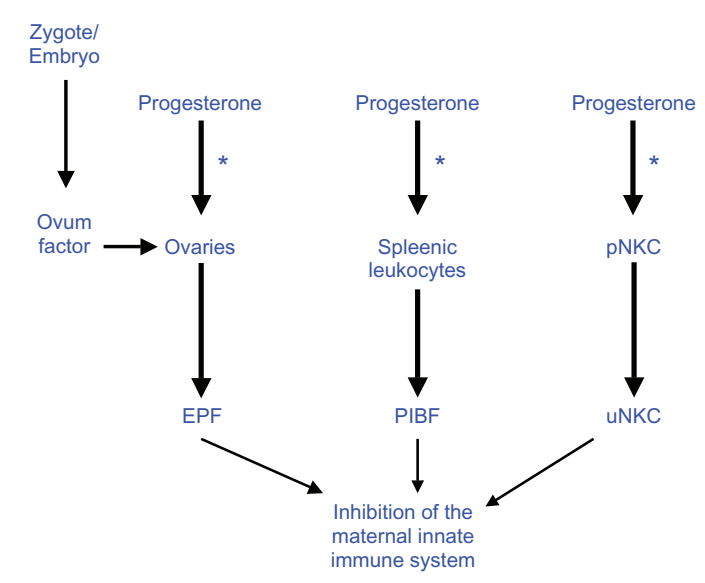

Figure I Immunosuppression of the innate immune system in pregnancy. Normal suppression of the maternal innate immune system begins with fertilization and is a result of EPF and progesterone-dependent secretion of T helper- 2 cytokines, the inhibitor of nuclear factor kappa beta, interleukin-10, and tumor growth factor beta. Note: *When blocked or modulated by ulipristal, the maternal immune innate system is free to immunologically attack the trophoblast cells of the implanting embryo in a host-versus-graft reaction.

Abbreviations: EPF, early pregnancy factor; PIBF, progesterone-induced blocking factor; pNKC, peripheral natural killer cell; uNKC, uterine natural killer cell. 
a factor that immunosuppresses the maternal immune system. ${ }^{77,78}$ This factor, PIBF, inhibits natural killer cell (NKC) cytotoxicity, stimulates production of asymmetrical antibodies, and increases interleukin (IL)-4 production. ${ }^{79,80}$ The net result of PIBF is to inhibit Th-1 cytokine responses and increase Th-2 responses. ${ }^{81-85}$ PIBF has been shown to have an anti-abortive effect in mice. NKC activity has been shown to be significantly lower in pregnant women when compared with nonpregnant women. Spontaneous abortions in women have been associated with increased NKC activity, and $\mathrm{NKCs}$ are recruited into the decidua during early pregnancy in both mice and humans. Spleenic cells from mice on day 8.5 of pregnancy treated with anti-PIBF immunoglobulin $\mathrm{G}$ had a fourfold increase in natural killer activity when sacrificed on day 10.5. Mice injected with mifepristone on day 8.5 of pregnancy and sacrificed on day 10.5 had an increased abortion rate and a decrease in PIBF-producing cells in the spleen. ${ }^{86,87}$ Early termination of pregnancy induced with mifepristone is associated with a disturbance of progesterone-mediated immunosuppression. ${ }^{88}$ It is reasonable to assume that ulipristal, a derivative of mifepristone, would exert the same effect as mifepristone on lymphocytes that synthesize and secrete PIBF during pregnancy.

\section{Phenotypic conversion of peripheral NKCs (pNKCs) to uterine NKCs (uNKCs)}

NKCs provide the first line of defense of the mIIS against transplanted semi-allogenic cells, tumor cells, and cells infected with bacteria or viruses. ${ }^{89-95}$ Cytotoxic materials are delivered from NKCs to adverse target cells via a cellular structure known as an immune synapse that is composed of microscopic nanotubes. ${ }^{96-98}$ Chemokines and cytokines are secreted by the implanting embryo, resulting in the recruitment of maternal pNKCs $\left(\mathrm{CD} 56^{\mathrm{dim}} \mathrm{CD} 16^{+}\right) .{ }^{99}$ These pNKCs under the direct influence of progesterone undergo a phenotypical conversion to uNKCs (CD56 $\left.{ }^{\text {bright }} \mathrm{CD} 16^{-}\right)$and regulate embryo development. ${ }^{100-102}$ This conversion appears to be controlled by the trophoblast secretion of tumor growth factor-beta into the local environment of the decidua. ${ }^{94,103}$ Furthermore, chorionic gonadotrophin (hCG), secreted by the preimplantation developing embryo within the fallopian tube, contributes to maternal immunotolerance by regulating the Fas-Fas ligand system. ${ }^{104}$ Also, hCG is a stimulator of uNKC proliferation. ${ }^{103,105}$ The phenotypical uNKCs are crucial for the secretion of angiogenic factors, such as vascular endothelial growth factor for the remodeling of the vasculature of the spiral arteries in formation of the placenta. ${ }^{106-108}$ Low-dose mifepristone has been shown to act as an antiimplantation drug by causing a dysregulation of uNKCs during implantation. ${ }^{3}$ Progesterone suppression of tumor necrosis factor $\alpha$, IL-1 $\beta$, and IL-12 is prevented by mifepristone. ${ }^{3,109}$ It is postulated that ulipristal also acts in a similar manner to mifepristone in causing a dysregulation of uNKCs, resulting in the destruction of the embryo by NKCs.

\section{Summary}

The mechanism of action of a low-dose ulipristal (30 mg) as an EC has been attributed exclusively to the delaying of ovulation by 5 days. This particular mechanism of action occurs when both unprotected intercourse and the administration of ulipristal occur within the fertile window. However, a single low dose of ulipristal has a placebo effect when both unprotected intercourse and the administration of ulipristal occurs more than 24 hours after ovulation. Furthermore, when unprotected intercourse occurs during the fertile window and the administration of ulipristal occurs after ovulation, then ulipristal exerts an abortifacient action. It is proposed that the mIIS is responsible for the destruction of the implanting embryo via a host-versus-graft reaction involving ulipristal interference with EPF, PIBF, and decidual NKCs within the mIIS.

\section{Datasources}

MEDLINE, PubMed, and Google Scholar databases were searched (1980-June 2011). Key search terms were: progesterone, ulipristal, mifepristone, emergency contraceptives, early pregnancy factor, progesterone induced blocking factor, uterine natural killer cells, and pregnancy immunosuppression. Search of the literature was limited to the English language.

\section{Disclosures}

This paper was presented at the 2011 meeting of the American Association of the Pro-Life Obstetricians and Gynecologists. The author reports no conflicts of interest in this work.

\section{References}

1. Gellersen B, Fernandes MS, Brosens JJ. Non-genomic progesterone actions in female reproduction. Hum Reprod Update. 2009;15(1): 119-138.

2. Mesiano S, Wang Y, Norwitz ER. Progesterone receptors in the human pregnancy uterus: do they hold the key to birth timing? Reprod Sci. 2011; 18(1):6-19.

3. Butts CL, Candando KM, Warfel J, Belyavskaya E, D’Agnillo F, Sternberg EM. Progesterone regulation of uterine dendritic cell function in rodents is dependent on the stage of estrous cycle. Mucosal Immunol. 2010;3(5):496-505. 
4. King AE, Critchley HO. Oestrogen and progesterone regulation of inflammatory processes in the human endometrium. Steroid Biochem Mol Biol. 2010;31;120(2-3):116-126.

5. Salmon JE. A noninflammatory pathway for pregnancy loss: innate immune activation? J Clin Invest. 2004;114(1):15-17.

6. Davies CJ. Why is the fetal allograft not rejected? J Anim Sci. 2007; 85(13 Suppl):E32-E35.

7. Butts CL, Bowers E, Horn JC, et al. Inhibitory effects of progesterone differ in dendritic cells from female and male rodents. Gend Med 2008;5(4):434-447.

8. Mifeprisone induces maturation of monocyte-derived dendritic cells. http://www.china-papers.com/?p=3888. Accessed September 1, 2011.

9. Spitz IM. Mifepristone: where do we come from and where are we going? Clinical development over a quarter of a century. Contraception. 2010;82(5):442-452.

10. Aparicio IM, Garcia-Herreros M, O'Shea LC, Hensey C, Lonergan P, Fair T. Expression, regulation, and function of progesterone receptors in bovine cumulus oocyte complexes during in vitro maturation. Biol Reprod. 2011;84(5):910-921.

11. Pintiaux A, Chabbert-Buffet N, Foidart JM. Gynaecological uses of a new class of steroids: the selective progesterone receptor modulators. Gynecol Endocrinol. 2009;25(2):67-73

12. Spitz IM. Progesterone antagonists and progesterone receptor modulators: an overview. Steroids. 2003;68(10-13):981-993.

13. Chabbert-Buffet N, Meduri G, Bouchard P, Spitz IM. Selective progesterone receptor modulators and progesterone antagonists: mechanisms of action and clinical applications. Hum Reprod Update. 2005;11(3):293-307.

14. Katkam RR, Gopalkrishnan K, Chwalisz K, Schillinger E, Puri CP. Onapristone (ZK 98.299): a potential antiprogestin for endometrial contraception. Am J Obstet Gynecol. 1995;173(3 Pt 1):779-787.

15. HRA Pharma. NDA 22-474 Ulipristal Acetate [report on the Internet]. Silver Spring, MD: FDA; May 20, 2010. Available from: http://www fda.gov/downloads/AdvisoryCommittees/CommitteesMeetingMaterials/Drugs/ReproductiveHealthDrugsAdvisoryCommittee/UCM215425. pdf. Accessed Nov 10, 2011

16. Gemzell-Danielsson K, Meng CX. Emergency contraception: potential role of ulipristal acetate. Int J Womens Health. 2010;2:53-61.

17. Gemzell-Danielsson K. Mechanism of action of emergency contraception. Contraception. 2010;82(5):404-409.

18. Mansour D. EllaOne: a second-generation emergency contraceptive? Fam Plann Reprod Health Care. 2009;35(4):217-218.

19. Faculty of Sexual and Reproductive Healthcare of the Royal College of Obstetricians and Gynaecologists. Ulipristal acetate $\left(\right.$ ellaOne $\left.{ }^{\circledR}\right)$ [review]. United Kingdom: Faculty of Sexual and Reproductive Healthcare of the Royal College of Obstetricians and Gynaecologists; October 2009. Available from: http://www.ffprhc.org.uk/pdfs/ellaOneNewProduct Review1009.pdf. Accessed June 8, 2011.

20. Blithe DL, Nieman LK, Blye RP, Stratton P, Passaro M. Development of the selective progesterone receptor modulator CDB-2914 for clinical indications. Steroids. 2003;68(10-13):1013-1017.

21. Snow SE, Melilllo SN, Jarvis CI. Ulipristal acetate for emergency contraception. Ann Pharmacother. 2011;45(6):780-786.

22. Keenan JA. Uliristal acetate: contraceptive or contragestive? Ann Pharmacother. 2011;45(6):813-815.

23. Glasier AF, Cameron ST, Fine PM, et al. Ulipristal acetate versus levonorgestrel for emergency contraception: a randomised non-inferiority trial and meta-analysis. Lancet. 2010;375(9714):555-562.

24. Gemzell-Danielsson K, Marions L. Mechanisms of action of mifepristone and levonorgestrel when used for emergency contraception. Hum Reprod Update. 2004;10(4):341-348.

25. Lalitkumar PG, Lalitkumar S, Meng CX, et al. Mifepristone, but not levonorgestrel, inhibits human blastocyst attachment to an in vitro endometrial three-dimensional cell culture model. Hum Reprod. 2007; 11:3031-3037.

26. McKeage K, Croxtall JD. Ulipristal acetate: a review of its use in emergency contraception. Drugs. 2011;7:935-945.
27. Brache V, Cochon L, Jesam C, et al. Immediate pre-ovulatory administration of $30 \mathrm{mg}$ ulipristal acetate significantly delays follicular rupture. Hum Reprod. 2010;25(9):2256-2263.

28. Gemzell-Danielsson K, Meng CX. Emergency contraception: potential role of ulipristal acetate. Int J Womens Health. 2010;2: 53-61.

29. Creinin MD, SchlaffW, Archer DF, et al. Progesterone receptor modulator for emergency contraception: a randomized controlled trial. Obstet Gynecol. 2006;108(5):1089-1097.

30. Passaro MD, Piquion J, Mullen N, et al. Luteal phase dose-response relationships of the antiprogestin CDB-2914 in normally cycling women. Hum Reprod. 2003;18(9):1820-1827.

31. Reel JR, Hild-Petito S, Blye RP. Antiovulatory and postcoital antifertility activity of the antiprogestin CDB-2914 when administered as single, multiple, or continuous doses to rats. Contraception. 1998; 58(2):129-136.

32. Wilcox AJ, Weinberg CR, Baird DD. Timing of sexual intercourse in relation to ovulation. Effects on the probability of conception, survival of the pregnancy, and sex of the baby. N Engl J Med. 1995;7;333(23): $1517-1521$

33. FertilityFriend.com. The fertile window - scientific literature review [webpage on the Internet]. Ontario, Canada: Tamtris Web Services Inc; nd. Available from: http://www.fertilityfriend.com/Faqs/The-FertileWindow---Scientific-Literature-Review.html. Accessed June 8, 2011.

34. Harrison DJ, Mitroka JG. Defining reality: the potential role of pharmacists in assessing the impact of progesterone receptor modulators and misoprostol in reproductive health. Ann Pharmacother. 2011;45(1): 115-119.

35. Stratton P, Levens ED, Hartog B, et al. Endometrial effects of a single early luteal dose of the selective progesterone receptor modulator CDB-2914. Fertil Steril. 2010;93(6):2035-2041.

36. Meng CX, Andersson KL, Bentin-Ley U, Gemzell-Danielsson K, Lalitkumar PG. Effect of levonorgestrel and mifepristone on endometrial receptivity markers in a three-dimensional human endometrial cell culture model. Fertil Steril. 2009;91(1):256-264.

37. Sacks G, Sargent I, Redman C. An innate view of human pregnancy. Immunol Today. 1999;20(3):114-118.

38. Menzies FM, Henriquez FL. Immunomodulation by the female sex hormones. Open Infect Dis J. 2009;3:61-72.

39. Matthias G. Immune interactions and tolerance between mother and embryo. O\&G Magazine. 2007;9(4):14-17.

40. Walker CG, Meier S, Littlejohn MD, Lehnert K, Roche JR, Mitchell MD. Modulation of the maternal immune system by the pre-implantation embryo. BMC Genomics. 2010;13;11:474.

41. Gilbert SF. Implantation. Developmental Biology. 9th ed. Stamford, CT: Sinauer; 2010.

42. Trowsdale J, Betz AG. Mother's little helpers: mechanisms of maternalfetal tolerance. Nat Immunol. 2006;7(3):241-246.

43. Staun-Ram E, Shalev E. Human trophoblast function during the implantation process. Reprod Biol Endocrinol. 2005;20;3:56.

44. Guleria I, Pollard JW. The trophoblast is a component of the innate immune system during pregnancy. Nat Med. 2000;6(5): 589-593.

45. Mor G. Inflammation and pregnancy: the role of toll-like receptors in trophoblast-immune interaction. Ann N Y Acad Sci. 2008;1127: $121-128$.

46. Abrahams VM, Mor G. Toll-like receptors and their role in the trophoblast. Placenta. 2005;26(7):540-547.

47. Fujiwara H, Araki Y, Toshimori K. Is the zona pellucida an intrinsic source of signals activating maternal recognition of the developing mammalian embryo? J Reprod Immunol. 2009;81(1):1-8.

48. Erlebacher A, Zhang D, Parlow AF, Glimcher LH. Ovarian insufficiency and early pregnancy loss induced by activation of the innate immune system. J Clin Invest. 2004;114(1):39-48.

49. Barry FP, Murphy JM, English K, Mahon BP. Immunogenicity of adult mesenchymal stem cells: lessons from the fetal allograft. Stem Cells Dev. 2005;3:252-265 
50. Su L, Sun Y, Ma F, Lü P, Huang H, Zhou J. Progesterone inhibits Toll-like receptor 4-mediated innate immune response in macrophages by suppressing NF-kappaB activation and enhancing SOCS1 expression. Immunol Lett. 2009;125(2):151-155.

51. Stites DP, Siiteri PK. Steroids as immunosuppressants in pregnancy. Immunol Rev. 1983;75:117-138.

52. Szekeres-Bartho J, Halasz M, Palkovics T. Progesterone in pregnancy; receptor-ligand interaction and signaling pathways. J Reprod Immunol. 2009;83(1-2):60-64.

53. Roussev RG, Coulam CB. HLA-G and its role in implantation (review). J Assist Reprod Genet. 2007;24(7):288-295.

54. van Mourik MS, Macklon NS, Heijnen CJ. Embryonic implantation: cytokines, adhesion molecules, and immune cells in establishing an implantation environment. J Leukoc Biol. 2009;85(1):4-19.

55. Koga K, Aldo PB, Mor G. Toll-like receptors and pregnancy: trophoblast as modulators of the immune response. J Obstet Gynaecol Res. 2009; 35(2):191-202.

56. Piccinni MP. Role of T-cell cytokines in decidua and in cumulus oophorus during pregnancy. Gynecol Obstet Invest. 2007;64(3):144-148.

57. Hunt JS, Petroff MG, McIntire RH, Ober C. HLA-G and immune tolerance in pregnancy. FASEB J. 2005;19(7):681-693.

58. Bainbridge DR. Evolution of mammalian pregnancy in the presence of the maternal immune system. Rev Reprod. 2000;5(2):67-74.

59. Mueller MD, Vigne JL, Vaisse C, Taylor RN. Glycodelin: a pane in the implantation window. Semin Reprod Med. 2000;18(3):289-298.

60. Moffett-King A. Natural killer cells and pregnancy. Nat Rev Immunol. 2002;2(9):656-663.

61. Mao G, Wang J, Kang Y, et al. Progesterone increases systemic and local uterine proportions of $\mathrm{CD} 4+\mathrm{CD} 25+$ Treg cells during midterm pregnancy in mice. Endocrinology. 2010;151(11):5477-5488.

62. Steck T, Rieger L, Rödel E, Dietl J, Kämmerer U. Expression of the molecules HLA-G and HLA-E modulates cytokine production of monocyte generated dendritic cells. Zentralbl Gynakol. 2002;124(5): 304-309.

63. Robertson SA. Immune regulation of conception and embryo implantation-all about quality control? J Reprod Immunol. 2010;85(1): $51-57$.

64. Lin Y, Nakashima A, Shima T, Zhou X, Saito S. Toll-like receptor signaling in uterine natural killer cells - role in embryonic loss. $J$ Reprod Immunol. 2009;83(1-2):95-100.

65. Kanellopoulos-Langevin C, Caucheteux SM, Verbeke P, Ojcius DM. Tolerance of the fetus by the maternal immune system: role of inflammatory mediators at the feto-maternal interface. Reprod Biol Endocrinol. 2003;2(1):121.

66. Raghupathy R. Pregnancy: success and failure within the Th1/Th2/Th3 paradigm. Semin Immunol. 2001;13(4):219-227.

67. Choi BC, Polgar K, Xiao L, Hill JA. Progesterone inhibits in-vitro embryotoxic Th1 cytokine production to trophoblast in women with recurrent pregnancy loss. Hum Reprod. 2000;Suppl 1:46-59.

68. Arruvito L, Giulianelli S, Flores AC, et al. NK cells expressing a progesterone receptor are susceptible to progesterone-induced apoptosis. J Immunol. 2008;15;180(8):5746-5753.

69. Somodevilla-Torres MJ, Morton H, Zhang B, Reid S, Cavanagh AC. Purification and characterisation of functional early pregnancy factor expressed in Sf9 insect cells and in Escherichia coli. Protein Expr Purif. 2003;32(2):276-287.

70. Morton H. Early pregnancy factor: an extracellular chaperonin 10 homologue. Immunol Cell Biol. 1998;76(6):483-496.

71. Rolfe BE, Cavanagh AC, Quinn KA, Morton H. Identification of two suppressor factors induced by early pregnancy factor. Clin Exp Immunol. 1988;73(2):219-225.

72. Kobayashi S, Stice JP, Kazmin D, et al. Mechanisms of progesterone receptor inhibition of inflammatory responses in cellular models of breast cancer. Mol Endocrinol. 2010;24(12):2292-2302.

73. Wei JF, Zheng SS. NF-kappa B in allograft rejection. Hepatobiliary Pancreat Dis Int. 2003;2(2):180-183.
74. Jones LA, Anthony JP, Henriquez FL, Lyons RE, Nickdel MB, Carter KC, Alexander J, Roberts CW. Toll-like receptor-4-mediated macrophage activation is differentially regulated by progesterone via the glucocorticoid and progesterone receptors. Immunology. 2008, 125(1):59-69.

75. McCracken SA, Drury CL, Lee HS, Morris JM. Pregnancy is associated with suppression of the nuclear factor kappaB/IkappaB activation pathway in peripheral blood mononuclear cells. J Reprod Immunol. 2003;58(1):27-47.

76. Chow EK, Razani B, Cheng G. Innate immune system regulation of nuclear hormone receptors in metabolic diseases. J Leukoc Biol. 2007; 82(2):187-195.

77. Shojaeian J, Moazzeni SM, Nikoo S, Bozorgmehr M, Nikougoftar M, Zarnani AH. Immunosuppressive effect of pregnant mouse serum on allostimulatory activity of dendritic cells. J Reprod Immunol. 2007; 75(1):23-31.

78. Szekeres-Bartho J, Wegmann TG. A progesterone-dependent immunomodulatory protein alters the Th1/Th2 balance. J Reprod Immunol. 1996;31(1-2):81-95.

79. Gutierrez G, Gentile T, Miranda S, Margni RA. Asymmetric antibodies: a protective arm in pregnancy. Chem Immunol Allergy. 2005;89: 158-168.

80. Polgár B, Nagy E, Mikó E, Varga P, Szekeres-Barthó Urinary progesterone-induced blocking factor concentration is related to pregnancy outcome. J Biol Reprod. 2004;71(5):1699-1705.

81. Szekeres-Bartho J, Polgar B. PIBF: the double edged sword. Pregnancy and tumor. Am J Reprod Immunol. 2010;64(2):77-86.

82. Southcombe J, Redman C, Sargent I. Peripheral blood invariant natural killer $\mathrm{T}$ cells throughout pregnancy and in preeclamptic women. $J$ Reprod Immunol. 2010;87(1-2):52-59.

83. Anderle C, Hammer A, Polgár B, et al. Human trophoblast cells express the immunomodulator progesterone-induced blocking factor. $J$ Reprod Immunol. 2008;79(1):26-36.

84. Kozma N, Halasz M, Palkovics T, Szekeres-Bartho J. The progesteroneinduced blocking factor modulates the balance of $\mathrm{PKC}$ and intracellular Ca. Am J Reprod Immunol. 2006;55(2):122-129.

85. Makhseed M, Raghupathy R, Azizieh F, Omu A, Al-Shamali E, Ashkanani L. Th1 and Th2 cytokine profiles in recurrent aborters with successful pregnancy and with subsequent abortions. Hum Reprod. 2001;16(10):2219-2226.

86. Szekeres-Bartho J, Polgar B, Kozma N, et al. Progesterone-dependent immunomodulation. Chem Immunol Allergy. 2005;89:118-125.

87. Szekeres-Bartho J, Par G, Dombay G, Smart YC, Volgyi Z. The antiabortive effect of progesterone-induced blocking factor in mice is manifested by modulating NK activity. Cell Immunol. 1997;177(2): 194-199.

88. Salomon LJ, Rozenberg P, Szekeres-Bartho J, Malagrida L, GiudicelliY, Ville Y. Changes in progesterone-induced-blocking-factor expression rates following mifepristone administration in termination of pregnancy at 5 to 8 weeks. J Matern Fetal Neonatal Med. 2005;17(5): $353-356$.

89. Karimi K, Arck PC. Natural Killer cells: keepers of pregnancy in the turnstile of the environment. Brain Behav Immun. 2010;24(3): 339-347.

90. Koga K, Mor G. Toll-like receptors at the maternal-fetal interface in normal pregnancy and pregnancy disorders. Am J Reprod Immunol. 2010;63(6):587-600.

91. Riley JK, Yokoyama WM. NK cell tolerance and the maternal-fetal interface. Am J Reprod Immunol. 2008;59(5):371-387.

92. Kumar V, Medhi B. Emerging role of uterine natural killer cells in establishing pregnancy. Iran J Immunol. 2008;5(2):71-81.

93. Le Bouteiller P, Piccinni MP. Human NK cells in pregnant uterus: why there? Am J Reprod Immunol. 2008;59(5):401-406.

94. Saito S, Nakashima A, Myojo-Higuma S, Shiozaki A. The balance between cytotoxic NK cells and regulatory NK cells in human pregnancy. J Reprod Immunol. 2008;77(1):14-22. 
95. Dosiou C, Giudice LC. Natural killer cells in pregnancy and recurrent pregnancy loss: endocrine and immunologic perspectives. Endocr Rev. 2005;1:44-62.

96. Chauveau A, Aucher A, Eissmann P, Vivier E, Davis DM. Membrane nanotubes facilitate long-distance interactions between natural killer cells and target cells. Proc Natl Acad Sci U S A. 2010;107(12): 5545-5550.

97. Medical Research Council. Immune cells use 'bungee of death' to kill dangerous cells [press release]. Bexhill-on-Sea, United Kingdom: MediLexicon International Ltd; March 9, 2010. Available from: http:// www.medicalnewstoday.com/releases/181657.php. Accessed June 8, 2011.

98. Groer M, El-Badri N, Djeu J, Harrington M, Van Eepoel J. Suppression of natural killer cell cytotoxicity in postpartum women. Am J Reprod Immunol. 2010;63(3):209-213.

99. Kane N, Kelly R, Saunders PT, Critchley HO. Proliferation of uterine natural killer cells is induced by human chorionic gonadotropin and mediated via the mannose receptor. Endocrinology. 2009; 150(6):2882-2888.

100. Lin Y, Nakashima A, Shima T, Zhou X, Saito S. Toll-like receptor signaling in uterine natural killer cells - role in embryonic loss. J Reprod Immunol. 2009;83(1-2):95-100.

101. van den Heuvel M, Peralta C, Bashar S, Taylor S, Horrocks J, Croy BA. Trafficking of peripheral blood CD56(bright) cells to the decidualizing uterus - new tricks for old dogmas? J Reprod Immunol. 2005; 67(1-2):21-34.

102. King A, Burrows T, Verma S, Hiby S, Loke YW. Human uterine lymphocytes. Hum Reprod Update. 1998;4(5):480-485.
103. Keskin DB, Allan DS, Rybalov B, et al. TGFbeta promotes conversion of CD16+ peripheral blood NK cells into CD16- NK cells with similarities to decidual NK cells. Proc Natl Acad Sci U S A. 2007;104(9): 3378-3383.

104. Kayisli UA, Selam B, Guzeloglu-Kayisli O, Demir R, Arici A. Human chorionic gonadotropin contributes to maternal immunotolerance and endometrial apoptosis by regulating Fas-Fas ligand system. J Immunol. 2003;171(5):2305-2313.

105. Braverman Reproductive Immunology. Reproductive immunology [web page on the Internet]. New York: Braverman Reproductive Immunology; nd. Available from: http://www.reproductiveimmunology.com/ causes-of-miscarriage/immunologic-causes/reproductive-immunology/. Accessed June 8, 2011.

106. Kalkunte SS, Mselle TF, Norris WE, Wira CR, Sentman CL, Sharma S. Vascular endothelial growth factor $\mathrm{C}$ facilitates immune tolerance and endovascular activity of human uterine NK cells at the maternal-fetal interface. J Immunol. 2009;182(7):4085-4092.

107. Dosiou C, Giudice LC. Natural killer cells in pregnancy and recurrent pregnancy loss: endocrine and immunologic perspectives. Endocr Rev 2005;26(1):44-62.

108. Henderson TA, Saunders PT, Moffett-King A, Groome NP, Critchley HO. Steroid receptor expression in uterine natural killer cells. J Clin Endocrinol Metab. 2003;88(1):440-449.

109. Zhu HX, Zhang WW, Zhuang YL, Huang LL. Mifepristone as an anti-implantation contraceptive drug: roles in regulation of uterine natural killer cells during implantation phase. Am J Reprod Immunol. 2009;61(1):68-74.
International Journal of Women's Health

\section{Publish your work in this journal}

The International Journal of Women's Health is an international, peerreviewed open-access journal publishing original research, reports, reviews and commentaries on all aspects of women's healthcare including gynecology, obstetrics, and breast cancer. Subject areas include: Chronic conditions (migraine headaches, arthritis, osteoporosis);

\section{Dovepress}

Endocrine and autoimmune syndromes; Sexual and reproductive health; Psychological and psychosocial conditions. The manuscript management system is completely online and includes a very quick and fair peer-review system. Visit http://www.dovepress.com/ testimonials.php to read real quotes from published authors. 